\title{
Pemberian Antikoagulan Pada Wanita Hamil Dengan Katup Prostetik Mekanik
}

\author{
Putri Yeantesa ${ }^{1,2}$, Yerizal Karani ${ }^{1,2}$ \\ ${ }^{1}$ Bagian Kardiologi dan Kedokteran Vaskular, Fakultas Kedokteran Universitas Andalas, Padang, \\ Sumatera Barat; ${ }^{2}$ Bagian Kardiologi dan Kedokteran Vaskular, Rumah Sakit Umum Pusat Dr. M. Djamil, \\ Padang, Sumatera Barat
}

Korespondensi: Putri Yeantesa; alamat e-mail : yeantesa@yahoo.com; no. ponsel: 8116613150

\begin{abstract}
Abstrak
Antikoagulan sangat penting dalam berbagai macam kondisi pada wanita dalam usia reproduktif. Penggunaannya selama kehamilan meningkatkan risiko perdarahan dan efek buruk lainnya pada ibu dan janin. Kami melaporkan kasus seorang pasien wanita usia 37 tahun, gravida 3536 minggu, dengan riwayat mitral valve replacement (MVR) dengan katup mekanik yang dirawat untuk persiapan kehamilan. Pasien mendapatkan terapi antikoagulan warfarin sebelumnya. Selama perawatan, warfarin diganti dengan heparin dengan target activated partial thromboplastin time (aPTT) 1,5-2 kali kontrol. Namun, target ini sulit dicapai meskipun pemberian heparin mencapai dosis maksimal. Pasien dipantau dengan ketat untuk munculnya tanda-tanda tromboemboli selama perawatan. Terminasi kehamilan dilakukan pada usia kehamilan 38 minggu tanpa adanya komplikasi akibat pemberian antikoagulan selama kehamilan dan terapi warfarin dilanjutkan kembali setelah persalinan. Tatalaksana dengan antikoagulan selama kehamilan harus dipertimbangkan dengan hatihati, dengan pemilihan yang bijaksana dari agen antikoagulan, dan disertai pemantauan perubahan fisiologi kehamilan untuk menetapkan dosis yang tepat.
\end{abstract}

Kata kunci: Antikoagulan; kehamilan; MVR

\section{Abstract}

Anticoagulants are very important in various conditions in women of reproductive age. Their use during pregnancy increases the risk of bleeding and other adverse effects on the mother and fetus. Here, we reported a female patient aged 37 years, 35-36 weeks pregnant, with a history of mitral valve replacement (MVR) with mechanical valves. She was admitted for the labor preparation considering her treatment history of warfarin therapy. During the care, warfarin was replaced with heparin with aPTT target at 1.5-2 times that of control. Nevertheless, the target value was difficult to achieve despite the maximum dose of heparin administration. The patient was closely monitored for thromboembolic signs. Pregnancy was terminated at 38 weeks without any complications and warfarin therapy was resumed after delivery. Anticoagulants administration during pregnancy should be carefully considered with prudent selection of anticoagulant agents, followed by close monitoring of physiological changes in pregnancy to determine the right dose.

Keywords: Anticoagulant; pregnancy; MVR 


\section{PENDAHULUAN}

Antikoagulan sangat penting dalam berbagai macam kondisi pada wanita dalam usia reproduktif. Antikoagulan berguna pada banyak keadaan, penggunaannya selama kehamilan meningkatkan risiko perdarahan dan efek buruk lainnya pada ibu dan janin. Tatalaksana dengan antikoagulan selama kehamilan harus dipertimbangkan dengan hati-hati, dengan pemilihan yang bijaksana dari agen antikoagulan, dan dengan gambaran terhadap perubahan fisiologik dari kehamilan untuk menetapkan dosis yang tepat. ${ }^{1}$

Pemberian antikoagulan dan aspirin jangka panjang perlu diberikan karena risiko dari tromboemboli pada pasien dengan katup prostetik mekanik yang banyak terjadi pada tahun pertama setelah operasi. Kehamilan pada wanita dengan katup jantung mekanik menyebabkan risiko kematian maternal dari trombosis katup sekitar 1-4\%. Tanpa antikoagulan dan aspirin, kejadian tromboemboli tiga sampai enam kali lebih tinggi dibandingkan pemberian pengobatan dengan dosis yang tepat. ${ }^{2,3}$

Risiko dari trombosis katup dicatat antara 0,7 dan $6 \%$ per pasien per tahun (lebih dari $1,3 \%$ untuk trombosis menyebabkan obstruksi aliran darah). Risiko ini dapat meningkat jadi $25 \%$ pada pemberian antikoagulan yang tidak adekuat. Risiko dari trombosis katup prostetik lebih tinggi pada katup mekanik dibandingkan katup biologis dan meningkat oleh status hiperkoagulasi pada kehamilan dan adanya interupsi terhadap antikoagulan. ${ }^{4}$

Pada laporan kasus ini akan dibahas tatalaksana antikoagulan pada kehamilan dengan riwayat katup prostetik mekanik.

\section{METODE}

Loporan Kasus

\section{LAPORAN KASUS}

Seorang pasien, wanita berusia 37 tahun datang ke Poliklinik Jantung Rumah Sakit (RS) Dr. M. Djamil, Padang, dengan tujuan untuk kontrol ulang dan mendapatkan obat tambahan. Pasien sudah dikenal dengan riwayat mitral valve replacement (MVR) akibat penyakit mitral stenosis (MS) berat dan rutin mendapatkan pengobatan warfarin $4 \mathrm{mg}$ per hari. Pasien juga sedang hamil anak kelima dengan usia kehamilan 35-36 minggu. Pasien disarankan untuk rawat inap dengan tujuan bridging dari warfarin ke heparin untuk persiapan persalinan yang direncanakan akan dilakukan pada usia kehamilan 38 minggu. Pasien mempunyai riwayat pergantian katup mitral dengan katup mekanik 11 bulan yang lalu di RS Harapan Kita Jakarta. Sebelum operasi, pasien sering mengeluhkan sesak nafas, berdebar, dan nyeri dada yang memberat saat beraktivitas sejak tiga tahun terakhir. Pada saat kehamilan trimester pertama pasien juga pernah dirawat untuk heparinisasi. 
Pada pemeriksaan fisik, ditemukan tanda vital dalam batas normal, indeks massa tubuh (IMT) $27 \mathrm{~kg} / \mathrm{m}^{2}$. Pada pemeriksaan mata ditemukan konjungtiva anemis. Pada pemeriksaan paru tidak ditemukan tanda bendungan paru dan pada pemeriksaan jantung ditemukan batas jantung yang membesar dengan suara jantung iregular dan terdengar metalic sound. Pada pemeriksaan abdomen, didapatkan fundus uteri sesuai dengan usia kehamilan 35-36 minggu. Ekstremitas teraba hangat dan tidak ditemukan edema pada kedua tungkai.
Pada pemeriksaan elektrokardiografi, didapatkan irama fibrilasi atrium, frekuensi QRS 100x/menit, aksis normal, gelombang $P$ dan interval PR sulit dinilai, durasi QRS 0,04", perubahan ST-T tidak ada, tanda pembesaran ventrikel kanan dan kiri tidak ada. Pada rontgen toraks setelah operasi MVR tanggal 3 Oktober 2013 di RS Harapan Kita Jakarta, didapatkan cardio-thoracic ratio (CTR) 70\%, segmen aorta dan pulmonal dalam batas normal, pinggang jantung mendatar, apeks tertanam, dan tidak tampak adanya kongesti dan infiltrat.

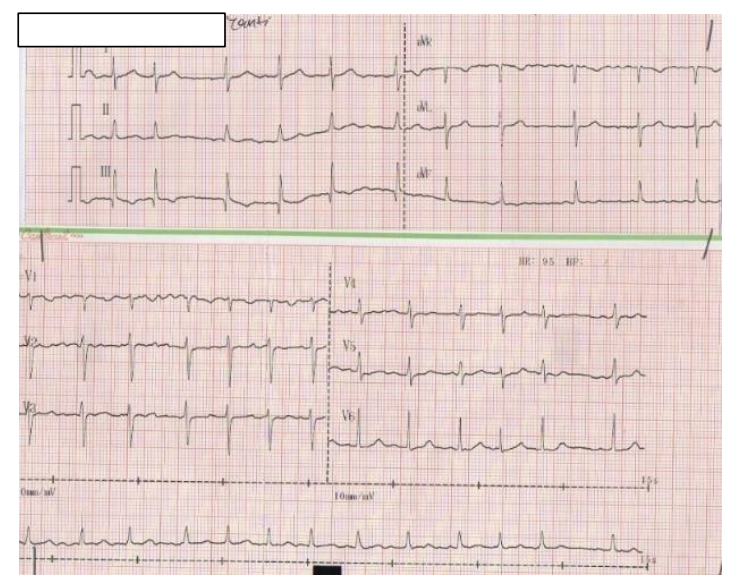

Gambar 1. Elektrokardiografi pada saat rawatan.

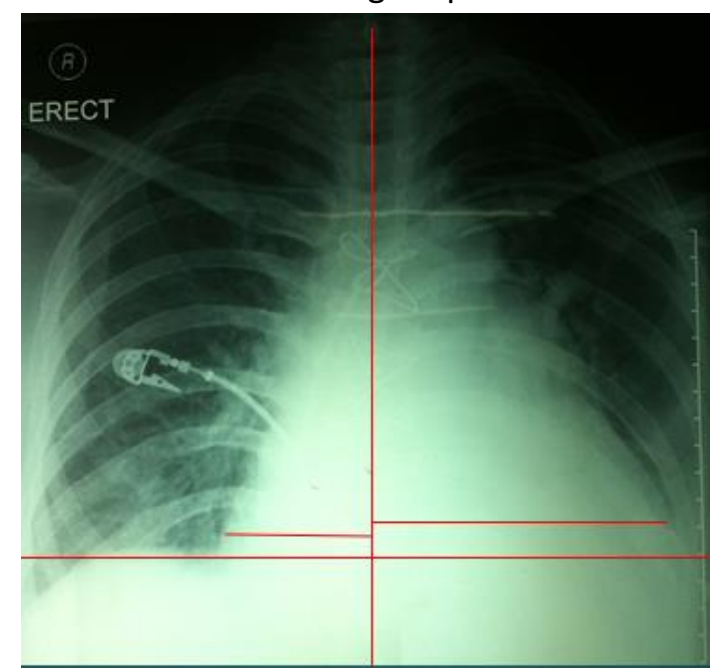

Gambar 2. Rontgen toraks setelah operasi di RS Harapan Kita, Jakarta. 
Pada pemeriksaan laboratorium didapatkan anemia ringan mikrositik hipokrom (hemoglobin 8,4 mg/dl), hipokalemia ringan $(3,4 \mathrm{mmol} / \mathrm{l})$, penanda koagulasi tercapai dengan prothrombin time (PT) 25,9', activated partial thromboplastin time (aPTT) 49,5', international normalized ratio (INR) 2,3 dan pemeriksaan laboratorium lainnya dalam batas normal.

Pada saat sebelum operasi, hasil ekokardiografi di RS Harapan Kita tanggal 12 Agustus 2013 menunjukkan adanya stenosis mitral berat, regurgitasi mitral ringan hingga sedang et causa penyakit jantung rematik, regurgitasi aorta ringan, regurgitasi trikuspid berat, fraksi ejeksi ventrikel kiri $67 \%$, fungsi ventrikel kanan menurun. Setelah operasi, hasil ekokardiografi didapatkan katup mitral mekanik dengan fungsi baik, tidak ada kebocoran, katup trikuspid pasca perbaikan, terdapat regurgitasi trikuspid residual ringan, fraksi ejeksi 61\%. Pada perawatan kali ini, pada pasien dilakukan ekokardiografi dengan hasil sama dengan ekokardiografi setelah operasi. Pada ekokardiografi didapatkan katup mitral mekanik yang berfungsi baik, pergerakan baik, tidak ada kebocoran, tidak ditemukan thrombus, dan terdapat pannus serta regurgitasi trikuspid ringan.
Pasien didiagnosis dengan pasca-MVR, fibrilasi atrium dengan respon ventrikel normal, G5P4AOH4 gravida 35-36 minggu, hypokalemia, dan anemia. Selama rawatan, pasien mendapatkan drip heparin yang disesuaikan dengan protocol. Pada awalnya diberikan drip $18 \mathrm{lU} / \mathrm{kgBB} / \mathrm{jam}$ dengan target aPTT 2-3 kali kontrol, dan untuk hipokalemi dilakukan koreksi dengan $\mathrm{KCl} 20 \mathrm{mEq}$. Rencana selanjutnya untuk kontrol penanda pembekuan dilakukan pemeriksaan PT dan aPTT setiap 12 jam. Dilakukan pemeriksaan urine lengkap dan uji benzidine untuk penelusuran darah samar dan didapatkan dalam batas normal. Selama enam hari rawatan, pasien mendapatkan drip heparin sampai dosis maksimal namun belum mencapai nilai target aPTT 2-3 kali kontrol sehingga protokol drip heparin diganti dengan pemberian subkutan dengan dosis 10.000-20.000 IU dua kali sehari dan dilakukan pemeriksaan PT dan aPTT enam jam setelah pemberian heparin. Dengan metode pemberian ini, nilai target aPTT 23 kali kontrol masih belum tercapai. Pemberian heparin tetap diberikan dengan dosis maksimal tanpa menaikkan dosis walaupun target aPTT tidak tercapai, karena khawatir terjadi komplikasi perdarahan pada ibu dan janin jika melebihi dosis tersebut. 


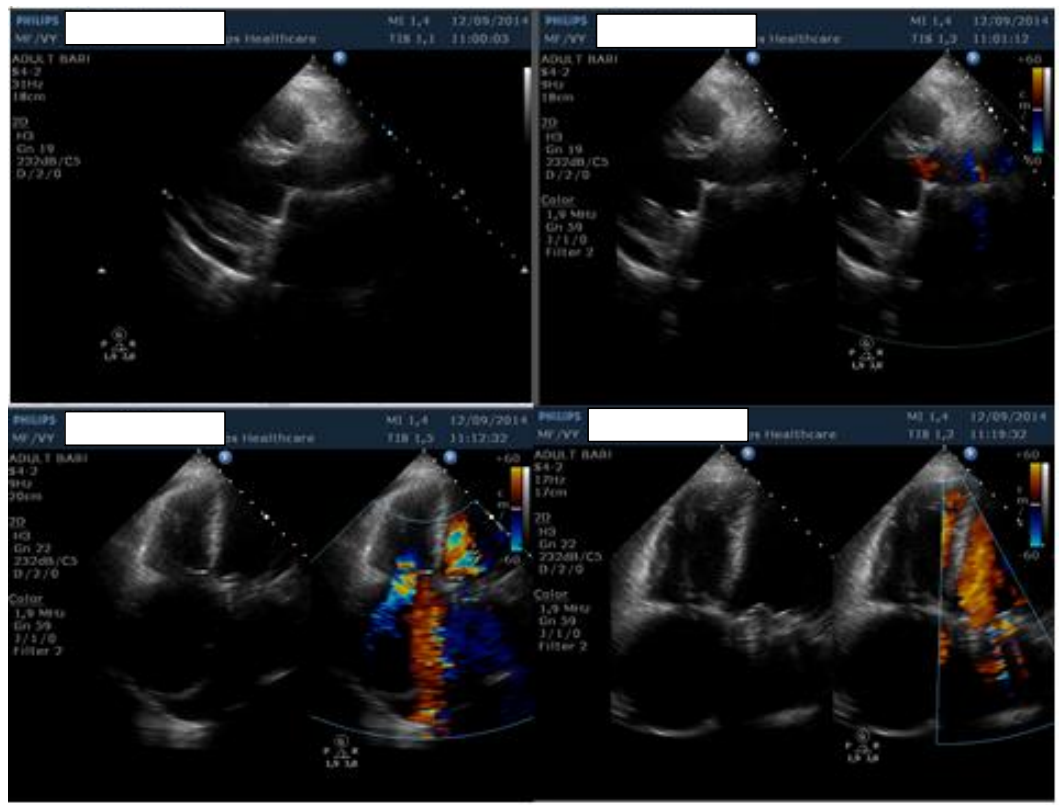

Gambar 3. Ekokardiografi pada saat rawatan.

Pasien dirawat bersama dengan Bagian Obstetri. Hasil konsultasi dengan Bagian Obstetri didapatkan ibu dan janin dalam keadaan baik. Selama rawatan, dilakukan transfusi packed red cell untuk koreksi anemia dan persiapan sectio caesarea (SC) karena akan dilakukan sterilisasi setelah terminasi kehamilan. Pemantauan kondisi ibu dan janin dilakukan secara berkala setiap hari sampai kehamilan 38 minggu dan siap untuk dilakukan terminasi.

Setelah dua minggu rawatan, dilakukan terminasi kehamilan secara SC elektif pada usia kehamilan 38 minggu. Satu hari sebelumnya, dilakukan evaluasi dengan ekokardiografi untuk menilai apakah fungsi hemodinamik pasien stabil dan evaluasi trombus. Ekokardiografi menunjukkan hasil evaluasi hemodinamik baik dan tidak terdapat trombus. Pemberian drip heparin dihentikan enam jam sebelum operasi. Selama dan setelah operasi kondisi pasien dan bayi stabil. Setelah persalinan, pasien dirawat di Bagian Obstetri untuk pemantauan kondisi selama nifas. Pada hari kedua nifas, pemberian drip heparin dimulai lagi untuk bridging ke warfarin sambil dilakukan pemantauan tanda perdarahan, baik dari luka operasi maupun perdarahan nifas.

Tujuh hari setelah operasi, pasien dibolehkan rawat jalan dan mendapat terapi beta bloker dan warfarin, dengan INR sebelum pulang 2,5 tanpa adanya perdarahan nifas yang berlebih akibat pemberian antikoagulan. Pasien disarankan untuk kontrol ke poliklinik untuk pemantauan rutin 


\section{DISKUSI}

Pada pasien ini terdapat riwayat MS sebelumnya dengan keluhan ada riwayat sesak yang meningkat saat aktivitas ringan dan sedang, dada berdebar-debar, dan cepat lelah. Pada pemeriksaan ekokardiografi sebelumnya didapatkan adanya MS berat disertai regurgitasi trikuspid berat, dan hipertensi pulmonal berat. Indikasi penggantian katup pada pasien ini adalah terdapatnya gejala yang berat, sesuai dengan NYHA fungsional kelas III/IV dengan MS berat. ${ }^{5}$

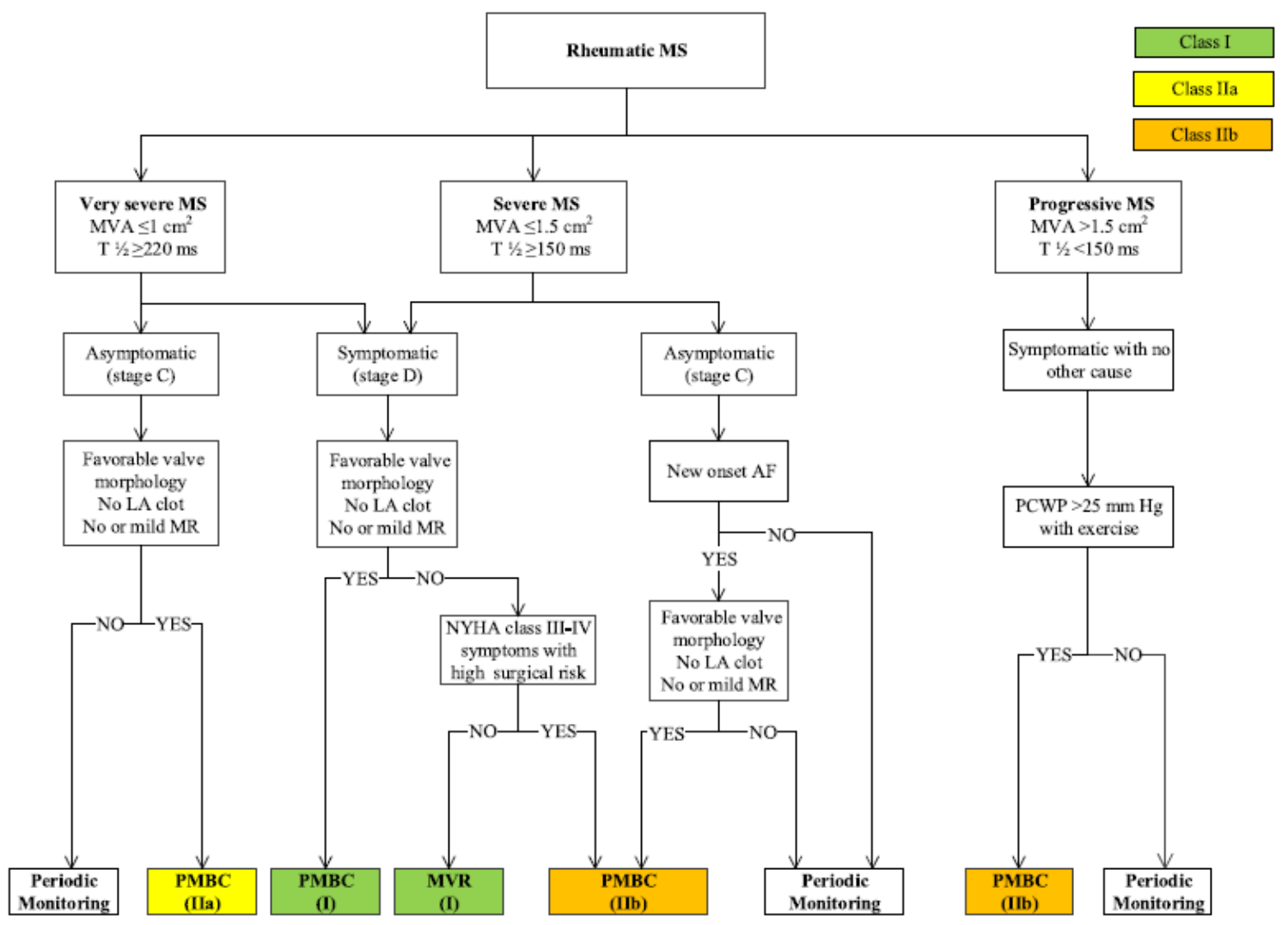

Gambar 4. Indikasi intervensi pada MS. ${ }^{6}$

Secara hemodinamik, wanita dengan katup mekanik yang fungsional dapat menjalani kehamilan dengan baik. Kebutuhan antikoagulan mendapatkan perhatian khusus karena meningkatkan risiko trombosis katup, komplikasi perdarahan, dan komplikasi pada janin. Kehamilan berhubungan dengan meningkatnya risiko maternal. Karakter dan besarnya risiko bergantung pada regimen antikoagulan yang digunakan selama kehamilan dan kualitas kontrol antikoagulan. Evaluasi sebelum kehamilan harus termasuk penilaian gejala dan evaluasi ekokardiografi fungsi ventrikel, katup prostetik, dan fungsi katup asli. ${ }^{7}$

Semua pasien dengan katup mekanik 
memerlukan terapi antikoagulan karena berhubungan dengan kejadian trombosis intravaskular pada material prostetik. Insiden tromboemboli lebih tinggi pada mitral dibanding aorta dan angka kejadian tromboemboli lebih rendah pada pasien dengan target INR yang lebih tinggi dibandingkan dengan target INR yang rendah. Pada pasien dengan katup mitral mekanik, target INR yang diharapkan adalah 3,0 (rentang 2,5-3,5), sedangkan pada panduan oleh European Society of Cardiology (ESC), target aPTT adalah 1,5-2 kali nilai kontrol. 5,6

Permasalahan pada kasus ini adalah pasien hamil dengan riwayat penggantian katup jantung prostetik mekanik yang membutuhkan terapi antikoagulan. Tujuan utama terapi antikoagulan pada pasien ini untuk mencegah kejadian trombosis dan konsekuensi letal untuk ibu dan janin. Menurut panduan ESC, warfarin harus dihindari pada trimester pertama karena berefek teratogenik, dan dalam 2-4 minggu sebelum persalinan untuk menghindari perdarahan janin. Pada trimester pertama (kehamilan 6-12 minggu), antikoagulan diganti dengan unfractionated heparin (UFH) atau low molecular weight heparin (LMWH) dengan pengontrolan dosis yang tepat. Pada trimester dua sampai kehamilan minggu ke-36, pasien direkomendasikan menggunakan antikoagulan oral, yaitu warfarin, dengan dosis yang tidak lebih dari $5 \mathrm{mg} / \mathrm{hari}$. Setelah minggu ke-36 hingga persalinan, anti koagulan kembali ditukar menjadi UFH. $6,7,8$

Warfarin dan heparin dapat digunakan selama kehamilan sebagai antikoagulan pada wanita hamil dengan katup jantung mekanik, namun potensial efek samping yang berhubungan terhadap maternal dan fetal dengan pengobatan ini cukup menantang. Wafarin memberikan perlindungan yang efektif terhadap tromboemboli, namun penggunaannya selama kehamilan berhubungan dengan peningkatan angka aborsi dan risiko embriopati. ${ }^{9}$

Heparin tidak diabsorbsi secara oral, karena itu diberikan secara subkutan atau intravena. Pemberian secara subkutan bioavailabilitasnya bervariasi, mula kerjanya lambat 1-2 jam tetapi masa kerjanya lebih lama. Heparin cepat dimetabolisme terutama di hati. Waktu paruhnya tergantung dosis yang digunakan. Suntikan intravena 100, 400, dan 800 unit/kgBB memperlihatkan masa paruh masing-masing kira-kira 1, 2, dan 5 jam. Heparin berat molekul rendah mempunyai waktu paruh yang lebih panjang daripada heparin standar. Metabolit inaktif dieksresikan melalui urine. Heparin dieksresikan secara utuh melalui urine hanya bila digunakan dosis besar intravena. Heparin tidak melalui plasenta dan tidak terdapat dalam air susu ibu. ${ }^{10}$

Warfarin merupakan antikoagulan oral yang bekerja sebagai antagonis vitamin $\mathrm{K}$. Warfarin mempengaruhi sintesis vitamin $\mathrm{K}$ yang berperan dalam pembekuan darah, sehingga terjadi deplesi faktor II, VII, IX dan $X$. Warfarin bekerja di hati dengan menghambat karboksilasi vitamin $\mathrm{K}$ dari protein prekursornya. Karena waktu paruh dari masing-masing faktor pembekuan 
darah tersebut, bila terjadi deplesi faktor VII maka waktu protrombin akan memanjang. Tetapi, efek antitrombotik baru mencapai puncak setelah terjadi deplesi keempat faktor tersebut. Jadi, efek antikoagulan dari warfarin membutuhkan waktu beberapa hari karena efeknya terhadap faktor pembekuan darah yang baru dibentuk bukan terhadap faktor yang sudah ada pada sirkulasi. Warfarin tidak mempunyai efek langsung terhadap trombus yang sudah terbentuk, tetapi dapat mencegah perluasan trombus. Pada pemberian warfarin, waktu protrombin harus dimonitor secara berkala. Mula kerja biasanya sudah terdeteksi di plasma dalam satu jam setelah pemberian, dengan waktu paruh 20-60 jam. Dosis inisial dimulai dengan 2-5 $\mathrm{mg} /$ hari dan dosis pemeliharaan 2-10 mg/hari. ${ }^{10}$

Warfarin berisiko teratogenik karena mampu melewati plasenta barrier, terutama selama awal usia kehamilan. Komplikasi warfarin pada semester pertama kehamilan termasuk: abortus spontan, prematuritas, deformitas fetal, lahir mati, perdarahan retro-plasenta dan perdarahan intrakranial. Warfarin embriopati terdiri dari abnormalitas tulang dan kartilago, nasal hiperplasia, optic atrophy, kebutaan, retardasi mental dan kejang. Banyak laporan terbaru dari efekefek yang berhubungan dengan dosis warfarin mengindikasikan pemberian yang aman selama kehamilan jika antikoagulan adekuat dapat tercapai dengan pemberian dosis 5 mg atau kurang. ${ }^{9}$

Unfractionaed heparin (UFH) merupakan terapi alternatif yang mencegah efek samping fetal. Namun, penggunaan UFH berhubungan dengan komplikasi tromboemboli dan perdarahan maternal. Pengukuran aPTT merupakan metode yang paling sering digunakan untuk monitoring respon antikoagulan dari UFH dan harus diukur enam jam setelah dosis bolus, dosis kontinu intravena disesuaikan sesuai nilai aPTT. Penggunaan heparin jangka panjang dapat menyebabkan osteoporosis. Sekitar 3\% pasien dengan UFH mengalami trombositopenia, dimana platelet turun $<100.000 / \mathrm{mm}^{3}$ atau $<50 \%$ dari nilai bawah dalam 5 sampai 15 hari setelah pemberian heparin. ${ }^{5,9,11}$

Low molecular weight heparin (LMWH) memiliki bioavaibilitas yang lebih baik dibandingkan UFH, dan memiliki risiko perdarahan, trombositopeni dan osteoporosis lebih rendah. Keuntungan ini, sayangnya, diimbangi dengan waktu paruh yang lebih lama (membuatnya sulit ditangani selama persalinan prematur), dan efek buruknya yang tidak dapat diprediksi dengan protamin. Pengaturan dosis LMWH berdasarkan level plasma anti-Xa empat jam setelah dosis awal. Target yang harus dipenuhi dari level antiXa adalah 1.0 sampai 1.2 unit per $\mathrm{ml}^{5}$ Penggunaan LMWH sebenarnya lebih baik dan nyaman untuk pasien, namun karena keterbatasan fasilitas di rumah sakit kami dimana tidak bisa dilakukan pemeriksaan level anti-Xa untuk pemantauan pengaturan dosis LMWH, maka diputuskan untuk menggunakan heparin yang dapat dikontrol penggunaan dosisnya dengan pengecekan aPTT secara berkala.

Rekomendasi dari American Consensus Conference (ACC) 2007 untuk terapi 
antitrombotik pada pasien dengan katup jantung mekanik terdapat tiga pilihan tatalaksana: ${ }^{5}$

1. Dosis tinggi (17.500-20.000 unit) subkutan UFH selama kehamilan diberikan dua kali sehari, dengan monitoring dosis (diharapkan enam jam setelah dosis aktivasi nilai aPTT dua kali kontrol, atau level anti-Xa dipertahankan 0,35-0,70 IU/ml).

2. LMWH (dalteparin 100 unit/kg) subkutan diberikan selama kehamilan dengan monitoring level anti-Xa sebagai petunjuk dosis (diharapkan empat jam setelah pemberian level anti-Xa sekitar 1,0 IU/ml).

3. Terapi UFH atau LMWH di atas sampai usia kehamilan 13 minggu, diikuti dengan warfarin sampai pertengahan semester tiga, lalu mulai kembali terapi UFH atau LMWH sampai melahirkan.

Setelah pemberian drip heparin selama enam hari, nilai aPTT yang diharapkan masih belum tercapai. Oleh karena itu, kami mengganti penggunaan drip heparin dengan pemberian secara subkutan sesuai dengan rekomendasi dari ACC. Namun, pada pemberian pertama kami memberikan dosis yang lebih rendah yaitu 10.000 IU karena sebelumnya pasien masih dalam drip heparin. Setelah itu dosis baru dinaikkan sesuai dengan rentang pemberian. Setelah pemberian heparin subkutan, nilai aPTT yang diharapkan masih belum bisa tercapai. Nilai aPTT pasien masih berkisar dalam nilai kontrol. Hal ini mungkin disebabkan hiperkoagulopati yang memang sering dialami oleh wanita hamil, dan pemberian heparin tidak kami berikan melebihi dosis yang dianjurkan karena dikhawatirkan dapat menyebabkan perdarahan, baik pada pasien atau janin. Dilakukan pemantauan ketat terhadap kemungkinan terjadinya trombus dengan melakukan penilaian metalic sound katup jantung secara berkala dan evaluasi trombus secara ekokardiografi setiap minggu.

Pada pasien ditemukan fibrilasi atrium dengan respon ventrikel normal. Menurut panduan American Heart Association (AHA), tatalaksana antiaritmia pada pasien dengan fibrilasi atrium dalam kehamilan lebih di rekomendasikan dengan pemberian digoksin, beta bloker, atau calcium channel blocker nondihydropiridine (rekomendasi kelas 1, level of evidence: C). Untuk rekomendasi pemberian antikoagulan selama trimester pertama dan bulan terakhir kehamilan pada pasien dengan fibrilasi atrium dan faktor risiko tromboemboli dipertimbangkan pemberian UFH dengan cara infus intravena yang berkelanjutan (aPTT 1,5-2 kali kontrol) atau dengan suntikan subkutan (10.000 - 20.000 IU/12 jam, disesuaikan dengan pemanjangan aPTT enam jam setelah penyuntikan sampai nilai 1,5 kali kontrol; rekomendasi kelas 2, level of evidence: B). Selama trimester dua, pertimbangan pemberian antikoagulan oral untuk wanita hamil dengan fibrilasi atrium dengan risiko tinggi tromboemboli (kelas 2, level of evidence: C). ${ }^{12}$

Pada pasien ini tidak diberikan obat untuk kontrol ventrikel karena denyut nadi masih dalam batas normal. Pasien juga telah 
dikenal lama memiliki irama fibrilasi atrium dengan hemodinamik dalam keadaan stabil.

Ditemukan anemia pada pasien ini, namun dari pemeriksaan tidak tampak adanya tanda tanda perdarahan aktif, dan pada pemeriksaan urine lengkap tidak ditemukan adanya hematuri dan darah samar pada feses. Pada pemeriksaan darah tepi ditemukan eritrosit mikrositik hipokrom yang mungkin mengarah pada defesiensi besi yang paling sering terjadi pada ibu hamil.

Terminasi kehamilan dilakukan pada usia kehamilan 38 minggu. Jika proses persalinan dimulai saat pengobatan dengan warfarin, maka SC harus dilakukan. Sebelum tindakan operasi, heparin dihentikan selama 4-6 jam. Jika tidak terdapat perdarahan yang signifikan setelah persalinan, heparin dapat dilanjutkan 4-6 jam setelah persalinan, dan warfarin oral dapat diberikan. ${ }^{12,13}$ Pada pasien ini sebenarnya tidak ada indikasi secara obstetri untuk dilakukan SC, namun mengingat pasien akan dilakukan tubektomi maka Bagian Obstetri memutuskan melakukan SC. Antikoagulan diberikan pada hari kedua nifas pada pasien ini karena dikhawatirkan pemberian warfarin yang terlalu awal dapat memicu perdarahan pada luka operasi maupun perdarahan per vaginam. Setalah melahirkan, pada pasien mulai dilakukan bridging untuk memulai terapi warfarin dengan pemberian heparin intravena selama tiga hari dan selanjutnya pasien dipulangkan dengan terapi antikoagulan warfarin saat target INR sudah tercapai. Terapi warfarin selama laktasi diperbolehkan. Warfarin sangat terikat dengan protein, tidak mudah dideteksi dalam ASI, dan yang penting tidak menyebabkan antikoagulasi pada bayi yang menyusui. Warfarin dapat digunakan tanpa ragu pada wanita dengan katup jantung mekanik yang menyusui. ${ }^{7}$

\section{KESIMPULAN}

Pasien pasca MVR dalam perjalanannya memerlukan antikoagulan untuk mencegah kejadian tromboemboli. Pada kasus pasien dalam keadaan hamil, pemberian antikoagulan harus dilakukan secara hati-hati dengan menimbang efek terhadap janin. Perlu dilakukan pemilihan antikoagulan yang tepat sesuai dengan usia kehamilan untuk mencegah efek samping obat baik untuk ibu maupun janin.

\section{DUKUNGAN FINANSIAL}

Penulis tidak memiliki dukungan finansial dari pihak luar dalam pembuatan laporan kasus ini.

\section{UCAPAN TERIMA KASIH}

Penulis mengucapkan terimakasih kepada pihak yang telah berpartisipasi dalam proses pembuatan laporan kasus ini hingga selesai.

\section{KONFLIK KEPENTINGAN}

Penulis tidak memiliki konflik kepentingan dalam proses pembuatan laporan kasus ini 


\section{DAFTAR PUSTAKA}

1. Gibson P, Powrie R. Anticoagulants and pregnancy: when are they safe?. Clev Clin J Med. 2009;76(2):113-127.

2. Kulik A, Rubens FD, Wells PS, Kearon C, Mesana TG, van Berkom J, Lam BK. Early postoperative anticoagulation after mechanical valve replacement: a systematic review. Ann Thorax Surg. 2006 Feb; 81(2): p.779.

3. Ginsberg J, Wee S, Bates S, Kaatz S. Anticoagulation of pregnant women with mechanical heart valves. Arch Inter Med. 2003;163(6): p.694.

4. Roudaut R, Serri K, Lafitte $S$. Thrombosis of prosthetic heart valves: diagnosis and therapeutic considerations. Heart. 2007; 93(1):137-142.

5. Srivastava. Anticoagulation for pregnant patients. Ann Card Anaesth. 2007; 10:95-107.

6. Nishimura, Otto C, Bonow R, Carabello B, Erwin J, Guyton R, et al. 2014 AHA/ACC Guideline for the management of patients with valvular heart disease: $A$ report of the American College of Cardiology/American Heart Association Task Force on Practice Guideline. J Am Heart Assoc. 2014;129(23):64-67.

7. Zagrosek VR, Lundqvist Cb, Borghi C, Cifkova R, Ferreira R, Foidart J, et al. ESC Guidelines on the management of cardiovascular diseases during pregnancy. Eur Heart J. 2011; 32:31703172 .

8. Kirchhof P, Benussi S, Kotecha D, Ahlsson A, Atar D, Casadei B, et al. 2016 ESC Guidelines for the management of atrial fibrillation developed in collaboration with EACTS. Eur Heart J. 2016;39(13):1-90.

9. Khamaushi A, Kashfi F, Husseini S. Anti-coagulation During Pregnancy in Woman with Mechanical Heart Valves: A Prospective Study. Royal Institute. Int Journal Fertil Steril. 2011;5(1):47-51.

10. Gunawan, gan sulistia. Farmakologi dan terapi edisi 5. Departemen Farmakologi dan Terapeutik FKUI.2007

11. Pieper P, Balci A, Vandijk A. Pregnancy in women with prosthetic heart valves. Neth Heart J. 2008;16(12):406-11.

12. Fuster V, Rydénv L, Cannom, Crijns H, Curtis H, Ellenbogen, et al. ACC/AHA/ESC 2006 Guidelines for the management of patients with atrial fibrillation. The European Heart Rhythm Association and the Heart Rhythm Society the Management of Patients With (Atrial Fibrillation): Developed in Collaboration With Committee for Practice Guidelines (Writing Committee to Revise the 2001 Guidelines for Association Task Force on Practice Guidelines and the European Society of Cardiology -Executive Summary: A Report of the American College of Cardiology/American Heart. J Am Heart Assoc. Circulation. 2006;114(7):700-52

13. Baron $T$, Kamath $P$, McBane R. Management of antithrombotic therapy in patients undergoing invasive procedures. N Engl J Med; 2013; 368:2113-2124 